\title{
Do ectomycorrhizal and arbuscular mycorrhizal temperate tree species systematically differ in root order-related fine root morphology and biomass?
}

\author{
Petra Kubisch, Dietrich Hertel and Christoph Leuschner* \\ Plant Ecology and Ecosystems Research, Albrecht von Haller Institute of Plant Sciences, University of Göttingen, Göttingen, Germany
}

Edited by:

Boris Rewald, University of Natural

Resources and Life Sciences,

Austria

Reviewed by:

Ivika Ostonen, University of Tartu,

Estonia

Jaana Leppälammi-Kujansuu,

University of Helsinki, Finland

\section{*Correspondence:}

Christoph Leuschner, Plant Ecology and Ecosystems Research, Albrecht von Haller Institute of Plant

Sciences, University of Göttingen, Untere Karspüle 2, 37073 Göttingen,

Germany

e-mail: cleusch@gwdg.de
While most temperate broad-leaved tree species form ectomycorrhizal (EM) symbioses, a few species have arbuscular mycorrhizas (AM). It is not known whether EM and AM tree species differ systematically with respect to fine root morphology, fine root system size and root functioning. In a species-rich temperate mixed forest, we studied the fine root morphology and biomass of three EM and three AM tree species from the genera Acer, Carpinus, Fagus, Fraxinus, and Tilia searching for principal differences between EM and AM trees. We further assessed the evidence of convergence or divergence in root traits among the six co-occurring species. Eight fine root morphological and chemical traits were investigated in root segments of the first to fourth root order in three different soil depths and the relative importance of the factors root order, tree species and soil depth for root morphology was determined. Root order was more influential than tree species while soil depth had only a small effect on root morphology All six species showed similar decreases in specific root length and specific root area from the 1st to the 4th root order, while the species patterns differed considerably in root tissue density, root $\mathrm{N}$ concentration, and particularly with respect to root tip abundance. Most root morphological traits were not significantly different between EM and AM species (except for specific root area that was larger in AM species), indicating that mycorrhiza type is not a key factor influencing fine root morphology in these species. The order-based root analysis detected species differences more clearly than the simple analysis of bulked fine root mass. Despite convergence in important root traits among AM and EM species, even congeneric species may differ in certain fine root morphological traits. This suggests that, in general, species identity has a larger influence on fine root morphology than mycorrhiza type.

Keywords: Acer, Carpinus, Fagus, Fraxinus, mixed stand, root tips, specific root area, Tilia

\section{INTRODUCTION}

Trees produce large amounts of woody coarse and large roots, but it is the small amount of fine non-woody roots which provide a large surface area and close contact to the soil enabling the absorption of water and nutrients. Conventionally, the most distal short-lived root segments with diameters $<2 \mathrm{~mm}$ ("fine roots") are associated with resource acquisition, while the thicker coarse and large roots are considered as being long-lived with transport, storage and anchorage function (Fitter, 1996; Pregitzer, 2002).

Recent root morphological research has shown that the distinction between fine and coarse roots with a fixed diameter threshold of $2 \mathrm{~mm}$ is not very useful for categorizing the root system of trees with respect to functionality, metabolic activity, and dynamics (Pregitzer et al., 1997, 2002; Pregitzer, 2002). It appears that certain root properties such as diameter, specific root surface area or tissue $\mathrm{N}$ concentration change more or less continuously with increasing distance from the terminal root tip, while anatomical features as cortex thickness, presence of secondary xylem, and the formation of a continuous cork layer as secondary peripheral tissue change more abruptly, perhaps in conjunction with branching events in the fine root system (Pregitzer et al., 2002; Guo et al., 2004). From the analysis of 23 temperate tree species, Guo et al. (2008) concluded that the shift in root function from resource absorption to transport occurs in the third or fourth root order, with branching events in the root system being counted in proximal direction from the terminal tip. Accordingly, root order was found to be a much better predictor of the functioning of a root segment than its diameter.

It is not well known how fine root morphology varies with the taxonomic position and ecology of trees. Differences in phylogenetic relatedness, mycorrhiza type (ectomycorrhizal vs. arbuscular mycorrhizal), growth rate (fast vs. slow), and successional position (early- vs. late-successional) all could possibly influence fine root morphology and fine root system architecture. Theoretically, the variability in fine root morphology among the 1500 or so temperate tree species could be as large as the variation observed in leaf morphology. Alternatively, coexisting tree species from different genera and families could develop convergent patterns of fine root morphology (Withington et al., 2006), at least when growing in the same stand, because a common dominant 
selective force controls root development. Root order related analysis of 23 Chinese (Guo et al., 2008) and 9 North American temperate tree species (Pregitzer et al., 2002) showed considerable species differences in fine root morphological, anatomical and chemical properties, even though some consistent general trends in branching patterns and anatomy along the fine root branches were detected.

The question of convergence or divergence in root system morphology and functionality is particularly interesting with respect to the distinction between ectomycorrhiza-forming (EM) and arbuscular mycorrhiza-forming (AM) trees. In the overwhelming majority of temperate tree species, the finest rootlets are colonized by ectomycorrhizal (EM) fungi. However, a few AM species are also present, coexisting with EM species in broad-leaved temperate mixed forests. Tree species, which mostly or exclusively form arbuscular mycorrhizas, are present, for example, in the temperate genera Acer, Fraxinus, Prunus, and Liriodendron. It is generally believed that AM-forming fungi of the phylum Glomeromycota have a positive effect on their host mainly through enhancement of the uptake of inorganic phosphorus, while EM-forming fungi support their host primarily by accessing organic nitrogen compounds (and other nutrient fractions) (George et al., 1995; Read and Perez-Moreno, 2003; Smith et al., 2003; Lang et al., 2011). Because most research on arbuscular mycorrhizas dealt with herbaceous plants, while research on EM primarily focused on trees, a direct functional comparison of these two major types of mycorrhizal association is complicated. We are not aware of a study that systematically searched for principal differences in fine root morphology between temperate EM- and AM-forming trees. Besides species and mycorrhiza type, a third factor with possible influence on fine root morphology is soil depth because soil physics and chemistry are exerting a large influence on root morphogenesis and growth (Wang et al., 2006).

In this study, we examined the variation in fine root morphology and architecture among six co-occurring temperate broadleaved tree species in a mixed forest, searching for evidence of divergence or convergence in fine root traits under uniform edaphic and climatic conditions. Because root functioning may largely depend on root branching patterns (Pregitzer et al., 1998; Pregitzer, 2002; Guo et al., 2008), we adopted a detailed root order-related analysis of fine root morphology. The six species were from five families (Oleaceae, Betulaceae, Tiliaceae, Fagaceae, and two species from Aceraceae), representing considerable phylogenetic and also functional diversity (three EM and three AM species). We investigated eight root morphological and chemical traits and related the observed trait variation across the six species-sample to the possible influence of root order, tree species, mycorrhiza type and soil depth. We also compared the species in terms of the amount of 1 st and 2 nd order fine root biomass in the topsoil. Main study goals were (1) to examine whether co-occurring species develop similar patterns of fine root system branching irrespective of phylogenetic relatedness, (2) to search for systematic differences in fine root architecture between EM and AM trees, (3) to compare the species in terms of fine root biomass assigned to root orders, and (4) to assess the advantages of adopting a root order-based analysis over a conventional analysis of bulked fine root material.

\section{MATERIALS AND METHODS STUDY SITE}

The study site is situated in Hainich National Park in Thuringia, Germany, which harbors old-growth beech forests (Fagus sylvatica L.) and relatively species-rich broad-leaved mixed forests on calcareous soil ( $350 \mathrm{~m}$ a.s.l.; $51^{\circ} 04^{\prime} \mathrm{N}, 10^{\circ} 30^{\prime} \mathrm{E}$ ). Suitable study plots were selected in the "Thiemsburg area" in the northeastern part of the national park where at least six tree species co-occur either in quasi-random mixture or in small groups consisting of three to six trees of a species. The species considered were those with highest abundance in this mixed forest (Stellario-Carpinetum association, "oak-hornbeam forests"): European beech (Fagus sylvatica L.), Small-leaved lime (Tilia cordata Mill.), European hornbeam (Carpinus betulus L.), European ash (Fraxinus excelsior L.), Sycamore maple (Acer pseudoplatanus L.) and Norway maple (Acer platanoides L.). Three of the six selected species have been found to form AM in Hainich forest (Acer pseudoplatanus, A. platanoides, and Fraxinus excelsior), the other three (Carpinus betulus, Fagus sylvatica, and Tilia cordata) EM (Lang et al., 2011). The investigated species are well studied with respect to aboveground morphological and functional properties (Withington et al., 2006; Köcher et al., 2009, 2013; Legner et al., 2013) and also in terms of fine root dynamics and root nitrogen and water uptake capacities (Korn, 2004; Meinen et al., 2009a,b; Jacob et al., 2012; Jacob and Leuschner, 2014; see Table SI 1 in the Supplement). Other forest patches are composed of up to 14 tree species including Prunus, Ulmus, and Quercus species as well (Meinen et al., 2009b). The majority of trees were about 90-150 years old (Schmidt et al., 2009) and mean canopy height of the dominant trees was 27-32 $\mathrm{m}$ with no larger canopy gaps present (average canopy openness 5.7\%, Seidel et al., 2012). The herb layer is patchy with an average cover of $\sim 17 \%$ in the studied stand (Vockenhuber et al., 2011). The forest was affected by only minor management activities (selective logging) in the past 50 years because part of the stand was used as military training area and all activities ceased in 1997 with the declaration of a national park.

The region has a semi-humid climate [mean annual temperature $7.7^{\circ} \mathrm{C}$, mean annual precipitation $\sim 590 \mathrm{~mm} \mathrm{yr}^{-1}$ (period 1973-2004; Deutscher Wetterdienst, 2005)]. In the study year 2011 , a mean annual temperature of $9.5^{\circ} \mathrm{C}$ and a precipitation of $470 \mathrm{~mm} \mathrm{yr}^{-1}$ were recorded (data of the nearby weather station Weberstedt/Hainich; Deutscher Wetterdienst, 2009).

The calcareous bedrock (Triassic limestone) is overlain by a base-rich Pleistocene loess layer which led to the development of eutrophic Luvisols (FAO taxonomy 2006) with a profile depth of $60-70 \mathrm{~cm}$ as the most widespread soil type in the study region. The soil texture of the mineral soil $(0-30 \mathrm{~cm})$ is characterized by high silt (about $74 \%)$ and low sand $(<5 \%)$ contents (Guckland et al., 2009). The soil can dry out strongly in summer and shows partly stagnant properties during spring and winter. Mainly through different foliar nutrient contents, the tree species influence soil chemistry resulting in some variation in topsoil $\mathrm{C} / \mathrm{N}$ ratio, base saturation and other properties underneath the six tree species (Table 1). Fagus patches showed accumulation of organic $\mathrm{Ol}$ and $\mathrm{Of}$ layers with slightly higher $\mathrm{C} / \mathrm{N}$ ratio of the mineral topsoil. Topsoil base saturation was somewhat lower under 
Table 1 | Stand and soil properties in the plots of the six species (means $\pm S E, n=8$ ).

\begin{tabular}{|c|c|c|c|c|c|c|}
\hline Parameter & F. excelsior & A. pseudoplatanus & A. platanoides & C. betulus & T. cordata & F. sylvatica \\
\hline \multicolumn{7}{|l|}{ STAND CHARACTERISTICS } \\
\hline Tree height (m) & $32.3 \pm 1.5$ & $28.6 \pm 0.9$ & $23.8 \pm 2.0$ & $22.8 \pm 1.1$ & $24.2 \pm 1.40$ & $26.4 \pm 0.7$ \\
\hline Basal area $\left(\mathrm{m}^{2} \mathrm{ha}^{-1}\right)$ & $57.1 \pm 5.4$ & $47.8 \pm 8.8$ & $28.7 \pm 2.5$ & $31.6 \pm 6.6$ & $50.9 \pm 6.0$ & $60.3 \pm 7.8$ \\
\hline Proportion target species $(\%)^{a}$ & $83.6 \pm 3.5$ & $62.7 \pm 7.2$ & $77.4 \pm 9.9$ & $86.1 \pm 8.0$ & $84.8 \pm 4.0$ & $90.4 \pm 5.7$ \\
\hline Base saturation (\%) & $91.2 \pm 4.3$ & $88.8 \pm 4.8$ & $87.3 \pm 6.8$ & $88.0 \pm 0.2$ & $93.4 \pm 0.2$ & $78.5 \pm 6.8$ \\
\hline Water content $(\%)^{b}$ & $37.9 \pm 5.5$ & $40.3 \pm 1.5$ & $38.8 \pm 7.1$ & $37.4 \pm 5.0$ & $36.2 \pm 3$ & $36.9 \pm 2.4$ \\
\hline $\mathrm{pH}\left(\mathrm{H}_{2} \mathrm{O}\right)$ & $4.65-6.30$ & $4.77-6.49$ & $4.72-6.96$ & $4.87-6.58$ & $4.81-6.70$ & $4.50-6.12$ \\
\hline
\end{tabular}

The data refer to all trees in a plot of $6 \mathrm{~m}$ radius. For $\mathrm{pH}$, the range of values is given.

a Of basal area.

bMay 2012.

Fagus (mean: 89\%) than under the other species (range of means: 92-96\%) while only minor $\mathrm{pH}$ variation was observed (Table 1).

\section{STUDY DESIGN}

Root coring was conducted at $150 \mathrm{~cm}$ distance to mature trees of the six target species with diameters at breast height $(\mathrm{dbh})$ of $40-60 \mathrm{~cm}$ and presence in the upper canopy layer. We selected either two neighboring trees of the target species and cored between them or conducted the coring in vicinity of one dominant tree of the respective species. This plot selection scheme in the mixed stand minimized possible species effects on soil chemistry (which would have been more pronounced in larger monospecific patches), while it guaranteed that the large majority (typically $>80 \%$ ) of the fine roots belonged to the target species. We sampled eight plots per species (i.e., 48 plots (tree clusters) in total) in a stand area of $\sim 15$ ha by randomly selecting trees of suitable species and dimension. Edaphic conditions were sufficiently homogenous to exclude soil-borne effects on fine root morphology, as they have been described by Ostonen et al. (2013). Mean distance between the plots was $\sim 50 \mathrm{~m}$ (minimum distance: $6 \mathrm{~m}$ ) which excludes possible root interactions between neighboring plots in nearly all cases. All stems $>10 \mathrm{~cm}$ dbh in a circle of $6 \mathrm{~m}$ radius around the root coring location were examined for their species identity, dbh, basal area and tree height (Table 1).

\section{SOIL SAMPLING AND FINE ROOT EXTRACTION}

Soil samples for root extraction were collected in June 2011 in the upper $30 \mathrm{~cm}$ of the soil in all 48 tree clusters using a steel corer of $35 \mathrm{~mm}$ diameter. The extracted soil was separated into the $0-10,10-20$, and $20-30 \mathrm{~cm}$ layers and stored in plastic bags at $4^{\circ} \mathrm{C}$ until final processing was conducted within 3 months. In the laboratory, the soil was gently washed with tap water over a sieve of $0.25 \mathrm{~mm}$ mesh width and all fine root branches (diameter $<2 \mathrm{~mm}$ ) of more than $10 \mathrm{~mm}$ length picked out with a pair of tweezers, placed under a microscope $(6-40 \times$ magnification), separated into live and dead mass and sorted by species. Criteria to distinguish between biomass (live) and necromass (dead) were root turgor, the elasticity of the stele, and the constitution of root stele and periderm (Leuschner et al., 2004; Rewald and Leuschner, 2009; Meinen et al., 2009a,b). Species identification was conducted with a morphological key based on periderm structure and color, root ramification, root tip morphology and the type of mycorrhiza developed which bases on earlier studies in this forest and elsewhere by lab members (Hölscher et al., 2002; Meinen et al., 2009b,c; Jacob et al., 2012). Characteristic branching features and surface properties of the fine root systems of the six species are displayed in pictures compiled in Figure SI 1 in the Supplement, where a brief description of fine root morphology is also given.

For determining the fine root biomass of the six species in the topsoil, the following two-step procedure was applied. After having sorted out the longer fine roots, the amount of finest rootlets $<10 \mathrm{~mm}$ length was examined in detail under a microscope for half of the samples (4 per species per soil depth). We dispersed the washed sample on filter paper $\left(730 \mathrm{~cm}^{2}\right)$ with 36 equal squares marked on it. Six of 36 squares were selected by random and the finest rootlets sorted into living and dead root mass (Van Praag et al., 1988; Hertel and Leuschner, 2002). The biomass and necromass of those six samples was extrapolated to the whole sample and in the following calculated for all samples. Because species identification was hardly possible in this fraction (which represented about 10 percent or less of the overall fine root mass), the species proportions detected in the $>10 \mathrm{~mm}$-samples were applied to this root fraction as well. We considered only the root mass of the tree species (target species and "other species" in a plot) but discarded the root mass of herbaceous species.

\section{MORPHOLOGICAL ANALYSIS}

All fine root branches of a core were subjected to morphological analysis shortly after collection. This was done separately for the three soil depths. Root segments with diameters $>2 \mathrm{~mm}$ were cut off. Specific root length (SRL, $\mathrm{m} \mathrm{g}^{-1}$ ), specific root area (SRA, $\mathrm{cm}^{2} \mathrm{~g}^{-1}$ ), root tissue density (RTD, $\mathrm{g} \mathrm{cm}^{-3}$ ) and mean root diameter $(\mathrm{MD}, \mathrm{mm})$ of the fine root sample were determined for all fine root branches of a sample by placing the roots in Petri dishes filled with purified water for scanning with a flatbed scanner (EPSON expression 1680, EPSON America Inc.); the scans were analyzed with WinRhizo 2005c software (Régent 
Instruments Inc., Québec, QC, Canada). The number of root tips was counted in all living root branches under the microscope (6-40 $\times$ magnification) and subsequently related to root dry mass. The ectomycorrhizal colonization rate (in \%) of the tips was calculated as:

$$
\left(\frac{\text { no. of mycorrhizal root tips }}{\text { no. of vital root tips }}\right) \times 100
$$

In the AM species, the root segments were inspected for colonization by hyphae, but quantitative data were not collected. Subsequently, a representative sub-sample of root strands (1 to maximal 6 per sample) was chosen for a root order-based characterization of traits, and the individual segments of the root samples were assigned to root branching orders according to Strahler's stream ordering system (Pregitzer et al., 2002) and dissected into the orders using a razorblade. For all species except Fraxinus excelsior, the root tip(s) plus the consecutive first root segment were counted as first-order segments, as it was not possible to clearly identify the transition between the root tip and the subsequent youngest root segment. In addition, root tips colonized by ectomycorrhizal fungi often formed coralloid clusters that were difficult to split into first and second-order segments. Ash root tips were well visible and were counted as first root order. SRL, SRA, RTD, and MD were separately determined for the root orders 1-4 using the flat-bed scanner and the Win-Rhizo software as described for the fine root bulk samples. In addition, the relative contribution (in percent) of the four root orders to the total biomass, length or surface area of the investigated root strand was determined in order to quantify biomass partitioning in the terminal part of the fine root system. After morphological investigation, the living root-material (entire root branches and separately analyzed fractions in the root orders) and the root necromass were dried at $70^{\circ} \mathrm{C}$ for $48 \mathrm{~h}$, weighed and ground for analysis of $\mathrm{C}$ and $\mathrm{N}$ concentrations by gas chromatography (Vario EL, elementar, Hanau, Germany). In the analyses, we distinguish between root order-related data and data relating to the bulk sample (all fine root biomass $<2 \mathrm{~mm}$, i.e., all 4 orders combined).

\section{DATA ANALYSIS}

All data sets were tested for normal distribution using a ShapiroWilk test. In most cases, normal distribution was not given and the non-parametric Mann-Whitney $U$-test for pairwise comparisons of means among species, soil depths and root orders was used for all morphological traits. For identifying the principal factors influencing root morphological traits, general linear models (GLM) based on ranks of the independent variables "species," "soil depth" and "root order" were calculated. Species comparisons (based on means of the $0-30 \mathrm{~cm}$ profile) were conducted using a general linear model (GLM) followed by a Scheffé-test. All test statistics were conducted with SAS 9.3 Windows software on a significance level of $p<0.05$. A Principal Components Analysis was conducted in the software CANOCO (biometris, Wageningen, The Netherlands) to analyze relationships between the five investigated root morphological traits and root orders. Linear and non-linear regressions were calculated with the software Xact7 (Sci Lab, Hamburg, Germany).

\section{RESULTS \\ SPECIES DIFFERENCES IN FINE ROOT MORPHOLOGY: BULK AND ROOT ORDER-RELATED ANALYSIS}

For comparing the six species, four morphological traits (MD, SRL, SRA, RTD) and root nitrogen concentration were analyzed either for the bulked fine root biomass (all segments $<2 \mathrm{~mm}$ in diameter pooled) or separately for the root order classes 14. In the root order-related analysis, we additionally determined the partitioning of root biomass, root length and surface area to the four studied root orders (expressed in percent of total biomass, length or surface area in the $<2 \mathrm{~mm}$ class) which allows assessing the relative importance of the four root order classes in the fine root system. The photographs in Figure SI 1 in the Supplement display characteristic fine root strands of the six species.

According to a GLM, all examined root morphological and chemical parameters were strongly dependent on species identity (Table 2). Nevertheless, the species effect was only secondary to the root order effect in all but one trait (RTD). In the bulked samples without separation of root orders, significant species differences existed for SRL and SRA (relatively high in the Acer species, intermediate in C. betulus, F. sylvatica, and F. excelsior, and relatively low in T. cordata), RTD (lower in F. excelsior than in the other five species), MD (higher in T. cordata, and F. excelsior, intermediate in F. sylvatica, A. platanoides, and C. betulus, and lower in A. pseudoplatanus) and root $\mathrm{N}$ concentration (elevated in F. excelsior, intermediate in C. betulus, the Acer species and F. sylvatica, relatively low in T. cordata; Table 3 ).

The number of root tips per fine root mass was relatively low in F. excelsior and T. cordata, intermediate in A. platanoides, C. betulus, and F. sylvatica, and highest in A. pseudoplatanus. Correspondingly, the number of tips per soil volume was particularly large in A. pseudoplatanus and F. sylvatica and low in $F$. excelsior, T. cordata and A. platanoides (Table 4).

The two congeners A. pseudoplatanus and A. platanoides had a remarkably different fine root morphology, in particular with respect to SRL and SRA (Figures 1E,F), even though they appeared to be morphologically similar under the microscope (Figure SI 1). The first-order rootlets of A. pseudoplatanus had a significantly higher SRL and SRA with a tendency for higher $\mathrm{N}$ concentration than those of $A$. platanoides in all three soil depths. A. pseudoplatanus also produced thinner 4th-order root segments with higher SRA than its congener (Figures 1A,E,F and Figure SI 1 in the Supplement). Further, A. pseudoplatanus forms significantly more fine root tips (per root mass and per soil volume) than A. platanoides (Table 4).

When comparing the three EM and three AM species, significant differences were only detected for one of the eight traits; SRA was larger in the AM than the EM species (Table 5). We did not get hints on systematic differences in root tip frequency between AM and EM species (Tables 4, 5) as it might be expected from the largely different morphology of the two mycorrhiza types. Downward in the soil profile (from 0-10 to $20-30 \mathrm{~cm}$ ), the AM species showed significant decreases in the number of fine root tips per soil volume and the cumulative length of first-order rootlets (which contain the tips) per volume; in contrast, no such trend was visible in the EM species (Table 4). However, AM and 
Table 2 | General linear models relating the variables "species," "soil depth," "root branching order" and their interactions to the dependent variables root biomass fraction, root surface area fraction, root length fraction, specific root length (SRL), specific root area (SRA), root tissue density (RTD), mean segment diameter (MD) and root $\mathrm{N}$ concentration (N) across the sample consisting of six tree species.

\begin{tabular}{|c|c|c|c|c|c|c|c|c|}
\hline Dependent variable & Model & Species & Depth & Order & Species $\times$ depth & Species $\times$ order & Depth $\times$ order & Species $\times$ depth $\times$ order \\
\hline$F$ & & 3.15 & 4.82 & 8.33 & 2.52 & & 2.90 & \\
\hline$R^{2}$ & 0.289 & 0.034 & 0.021 & 0.054 & 0.055 & & 0.038 & \\
\hline \multicolumn{9}{|c|}{ SURFACE AREA FRACTION } \\
\hline$R^{2}$ & 0.367 & 0.064 & 0.0164 & 0.128 & 0.062 & & 0.025 & \\
\hline \multicolumn{9}{|l|}{ LENGTH FRACTION } \\
\hline$F$ & & 13.66 & 21.58 & 141.06 & 3.16 & & & \\
\hline$p$ & 0.001 & 0.001 & 0.001 & 0.001 & 0.001 & & & \\
\hline$R^{2}$ & 0.643 & 0.074 & 0.047 & 0.460 & 0.034 & & & \\
\hline \multicolumn{9}{|l|}{ SRA } \\
\hline$F$ & & 10.68 & & 157.73 & & & & \\
\hline$p$ & 0.001 & 0.001 & & 0.001 & & & & \\
\hline$R^{2}$ & 0.646 & 0.060 & & 0.535 & & & & \\
\hline \multicolumn{9}{|l|}{ RTD } \\
\hline$F$ & & 23.36 & & 7.10 & & 2.24 & & \\
\hline$p$ & 0.001 & 0.001 & & 0.001 & & 0.01 & & \\
\hline$R^{2}$ & 0.393 & 0.223 & & 0.041 & & 0.060 & & \\
\hline \multicolumn{9}{|l|}{ MD } \\
\hline$F$ & & 31.24 & & 237.06 & & 2.54 & & \\
\hline
\end{tabular}

Given are the F-value, the significance level (p) and the $R^{2}$ values (only significant factors are presented).

EM species did not differ significantly with respect to tip numbers per soil volume.

In general, the influence of soil depth on root morphology was relatively small. Only in a few cases, we observed significant directional change in fine root morphological traits from the $0-10$ to the $20-30 \mathrm{~cm}$ layer. Notable is the increase in RTD with soil depth in A. pseudoplatanus and the decrease in root $\mathrm{N}$ concentration in C. betulus (Table 3).

Root order was the key factor influencing fine root traits (Table 2). According to the PCA, the morphological traits MD, SRA, and SRL showed the closest association with root order, which was located on the first PCA axis. In contrast, the association with order was weaker for the anatomical and chemical parameters N concentration and RTD (Table 6). All species showed a similar increase in root diameter and a decrease in SRA, SRL, and $\mathrm{N}$ concentration from the first to the fourth order, while the RTD pattern along the root was more variable among the species. F. excelsior differed from the other species by particularly low RTD and high N concentrations in all root orders (Figures 1D,H). The root order-based analysis revealed that the species differences were often pronounced in one order but negligible in others (as visible in MD and RTD; see Figure 1).

\section{SPECIES DIFFERENCES IN THE ABUNDANCE AND DISTRIBUTION OF FINE ROOT BIOMASS}

Total fine root biomass in the $0-30 \mathrm{~cm}$ profile (bulked samples) differed up to twofold among the six species with highest plot mean in F. sylvatica $\left(301 \mathrm{~g} \mathrm{~m}^{-2}\right)$ and lowest in A. platanoides ( $142 \mathrm{~g} \mathrm{~m}^{-2}$, difference significant at $\mathrm{p}<0.05$; Figure SI 2 in the Supplement). In the profile totals, $\sim 89-95 \%$ of root biomass was contributed by the target species and the remainder $\left(<25 \mathrm{~g} \mathrm{~m}^{-2}\right.$ in $0-30 \mathrm{~cm}$ ) by other woody species that grew in the neighborhood. Part of the species differences in fine root biomass seem to be caused by differences in the species' aboveground presence 


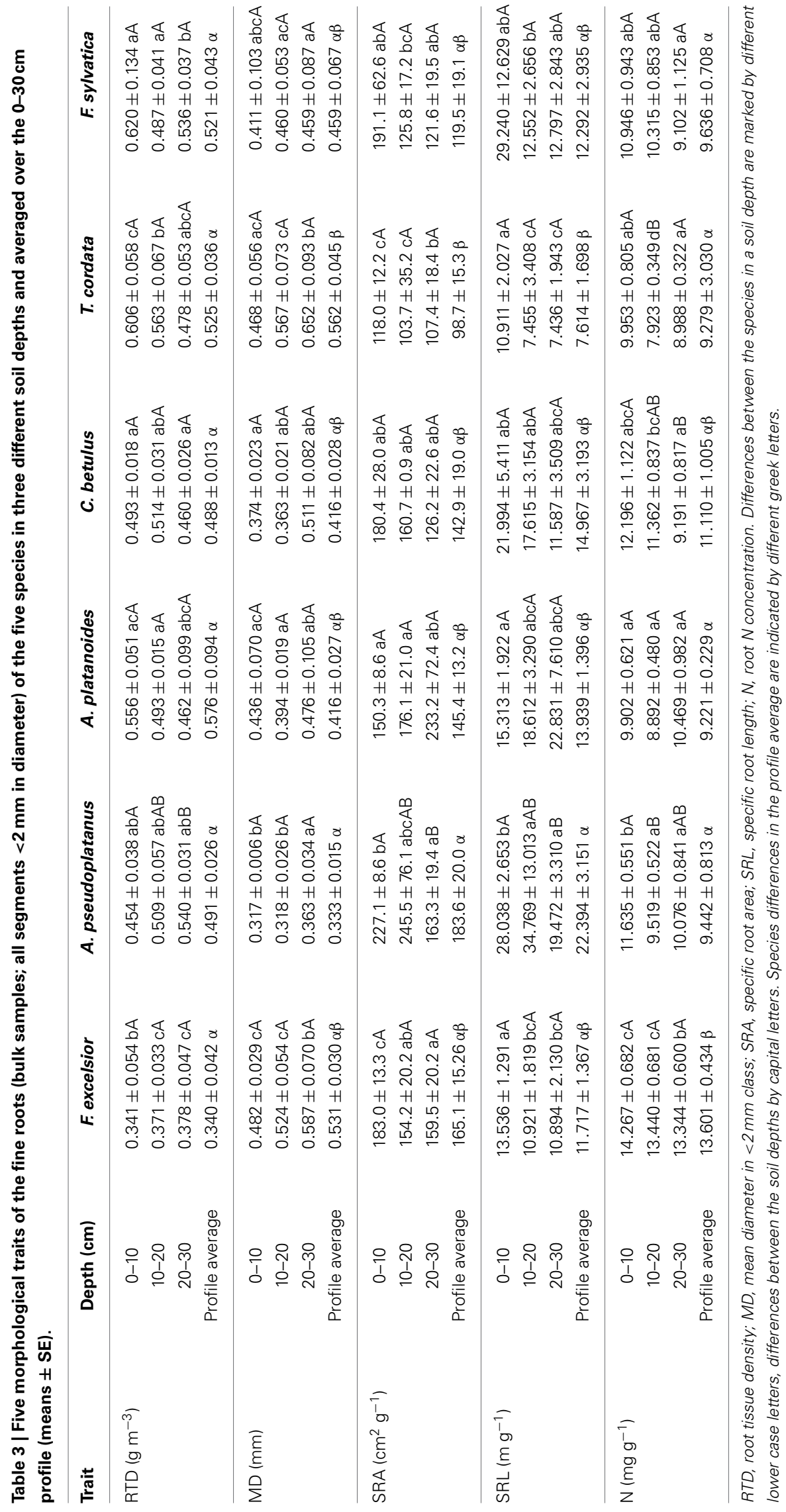


Table 4 | Root tips per biomass or soil volume, proportion of root tips colonized by EM fungi, tips per square meter soil and cumulative length of 1st-order root segments per liter soil volume for the six species in the three horizons and the entire profile $(0-30 \mathrm{~cm})$.

\begin{tabular}{|c|c|c|c|c|c|c|}
\hline Species & Soil depth (cm) & $\begin{array}{c}\text { Tips per } \mathrm{FR} \\
\text { biomass }\left(\mathbf{n ~}^{-1}\right)\end{array}$ & $\begin{array}{l}\text { Tips per soil } \\
\text { volume }\left(n \mathrm{~L}^{-1}\right)\end{array}$ & $\begin{array}{l}\text { Tips per square } \\
\text { meter }\left(\mathbf{n ~ m}^{-2}\right)\end{array}$ & $\begin{array}{l}\text { Proportion } \\
\text { infected }(\%)\end{array}$ & $\begin{array}{l}\text { Cumul. length of } 1 \text { st order } \\
\text { roots per soil volume }\left(\mathrm{m} \mathrm{L}^{-1}\right)\end{array}$ \\
\hline \multirow[t]{2}{*}{ F. excelsior } & $0-10$ & $1807 \mathrm{cA}$ & 2092 bA & 209151 & - & $8.13 \pm 1.24 \mathrm{dcA}$ \\
\hline & $20-30$ & 1654 bcA & $878 \mathrm{aB}$ & 87799 & - & $2.89 \pm 0.73 \mathrm{abB}$ \\
\hline Profile average & $0-30$ & $1466 \gamma$ & $1169 \alpha$ & $331894 \alpha x$ & - & $5.38 \pm 0.71 \alpha \beta$ \\
\hline A. pseudoplatanus & $20-30$ & $7155 \mathrm{aB}$ & $2861 \mathrm{bB}$ & 286061 & - & $4.38 \pm 1.09 \mathrm{aB}$ \\
\hline Profile average & $0-30$ & $8557 \beta$ & $4084 \beta$ & $1439768 \beta \delta$ & - & $7.31 \pm 0.56 \beta$ \\
\hline \multirow[t]{3}{*}{ A. platanoides } & $0-10$ & 4948 aA & 2349 aA & 234907 & - & $4.63 \pm 1.31 \mathrm{abAB}$ \\
\hline & $10-20$ & 5684 aA & $2063 \mathrm{aA}$ & 206294 & - & $4.49 \pm 0.98 \mathrm{aA}$ \\
\hline & $20-30$ & $8662 a b A$ & $720 \mathrm{aB}$ & 72047 & - & $1.62 \pm 0.81 \mathrm{bB}$ \\
\hline \multirow{2}{*}{ C. betulus } & $10-20$ & 5034 aA & 3799 bA & 379855 & $89.1 \pm 3$ & $6.62 \pm 0.98 \mathrm{bA}$ \\
\hline & $20-30$ & 3416 abcA & 1176 bB & 117579 & $98.1 \pm 1$ & $2.93 \pm 0.81 \mathrm{abB}$ \\
\hline Profile average & $0-30$ & $4578 \alpha$ & $2110 \gamma$ & $956849 \beta \chi \delta$ & $90.0 \pm 2$ & $4.77 \pm 0.72 \alpha \beta$ \\
\hline \multirow[t]{3}{*}{ T. cordata } & $0-10$ & $4769 \mathrm{aB}$ & $1738 \mathrm{abA}$ & 173775 & $74.8 \pm 8$ & $2.25 \pm 0.85 \mathrm{bA}$ \\
\hline & $10-20$ & 3789 bA & $2773 \mathrm{abA}$ & 277295 & $76.5 \pm 8$ & $3.15 \pm 1.37 \mathrm{acA}$ \\
\hline & $20-30$ & $1909 \mathrm{cA}$ & $1184 \mathrm{abA}$ & 118392 & $77.1 \pm 5$ & $3.37 \pm 0.39 \mathrm{abA}$ \\
\hline Profile average & $0-30$ & $2888 \gamma \delta$ & $1354 \alpha \gamma$ & $607816 \times \delta$ & $76.0 \pm 4$ & $2.14 \pm 0.63 \alpha$ \\
\hline \multirow[t]{3}{*}{ F. sylvatica } & $0-10$ & 11427 abcA & 3915 abA & 395314 & $88.8 \pm 6$ & $4.65 \pm 1.74 \mathrm{abdAB}$ \\
\hline & $10-20$ & $4604 \mathrm{abA}$ & $5410 \mathrm{bA}$ & 540977 & $86.3 \pm 4$ & $8.40 \pm 1.34 \mathrm{cbA}$ \\
\hline & $20-30$ & 5323 aA & 3686 bA & 368591 & $91.7 \pm 4$ & $5.06 \pm 1.25 \mathrm{aB}$ \\
\hline
\end{tabular}

Significant differences between species per soil depth are indicated by different lower case letters, differences for a species between soil depths by capital letters, differences between profile averages by greek letters.

in the plots as indicated by the variable basal areas of the species in the plots (28.7-60.3 $\mathrm{m}^{2} \mathrm{ha}^{-1}$, Table 1). However, the species may also differ inherently in their fine root biomass in the upper soil as indicated by large species differences in the fine root biomass/basal area ratio of the plots (range: 50-124 g fine root biomass per $\mathrm{m}^{2}$ basal area in the six species; data not shown).

Fine roots of $F$. sylvatica and T. cordata seemed to prefer the $10-20 \mathrm{~cm}$ layer (47 and $43 \%$ of the biomass profile total) over the top layer $(0-10 \mathrm{~cm})$ in the respective plots, while the other species showed similar fine root densities at 0-10, 10-20, and 20-30 cm depth (or a reduced density at 20-30 cm, Figure SI 2). Correspondingly, GLMs showed that soil depth had a smaller influence on fine root biomass variation across the study plots than species identity (Table 2).

\section{SPECIES DIFFERENCES IN THE ABUNDANCE OF 1st- AND 2nd-ORDER FINE ROOT BIOMASS}

A comparison of the six species with respect to the abundance of root biomass assignable to the 1st or 2 nd root orders revealed species differences in root system structure that would not have been detected by a comparison of bulked fine root biomass totals (Figure 2). F. sylvatica and T. cordata had a significantly smaller
1 st- and 2nd-order root biomass in the $0-10 \mathrm{~cm}$ layer than the other species. Due to the relatively small biomass proportion of the two species in these root orders, beech and lime differed from the other species more in 1st- and 2nd-order root biomass than in total fine root biomass. A. pseudoplatanus had significantly more 1 st- and 2nd-order root biomass in the $0-10 \mathrm{~cm}$ layer than its congener A. platanoides. Highest values in this layer were reached by F. excelsior.

In 10-20 cm depth, most species had higher amounts of 3rdand 4 th-order roots than in the top layer. 1st- and 2nd-order fine root biomass decreased toward the $20-30 \mathrm{~cm}$ layer and the degree of root branching decreased as well. As a consequence, four of the six species possessed only three root orders in this soil layer until roots exceeded $2 \mathrm{~mm}$ in diameter (Figure 2); thicker segments were cut off prior to analysis and thus were not investigated here.

\section{DISCUSSION \\ INTERSPECIFIC VARIATION IN FINE ROOT MORPHOLOGY AND BRANCHING PATTERNS}

Our root order-based analysis produced evidence for convergence in important fine root morphological traits and branching patterns across the six investigated species, even though most 


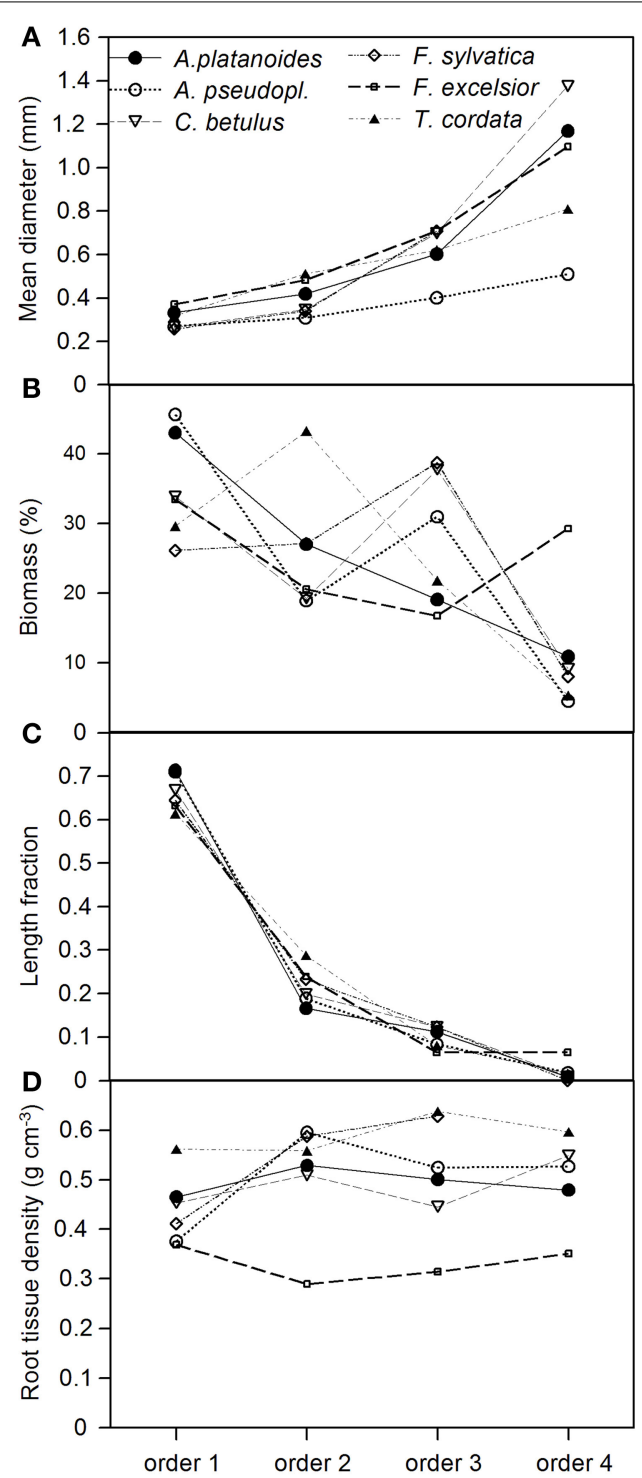

FIGURE 1 | Change in eight root morphological or chemical parameters $(A-H)$ along fine root strands from the first to the fourth root order in the six tree species (given are means of 8 replicate

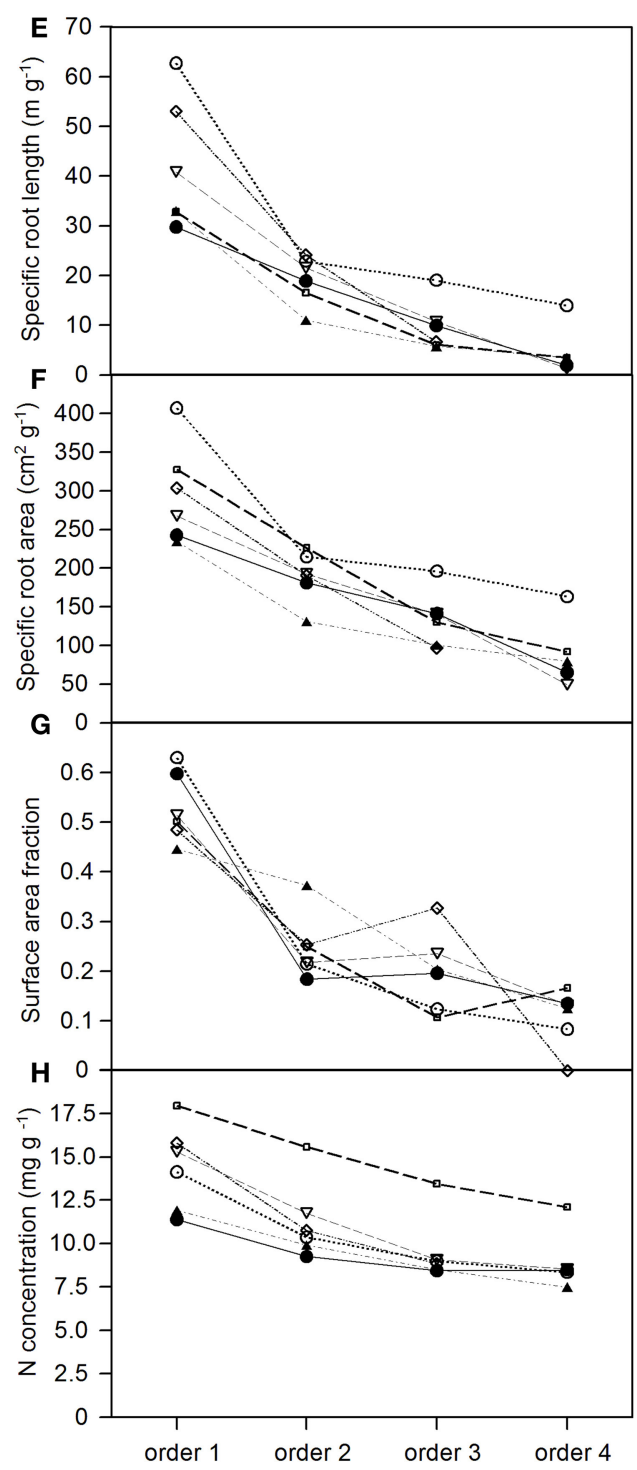

plots that were cored; each sample consisted of 1-6 roots that were averaged). All root strands had a maximum diameter of $2 \mathrm{~mm}$. The data refer to the $0-10 \mathrm{~cm}$ layer.

Table 5 | Means \pm SE of seven root morphological or chemical traits for the each three AM and EM species (data averaged over the 0-30 cm profile).

\begin{tabular}{|c|c|c|c|c|c|c|c|}
\hline Mycorrhiza type & $\mathrm{MD}(\mathbf{m m})$ & SRA $\left(\mathrm{cm}^{2} \mathrm{~g}^{-1}\right)$ & SRL $\left(\mathbf{m ~ g}^{-1}\right)$ & RTD $\left(\mathrm{g} \mathrm{cm}^{-3}\right)$ & $\mathbf{N}\left(\mathbf{m g ~ g}^{-1}\right)$ & Tips per mass $\left(g^{-1}\right)$ & Tips per volume $\left(\mathrm{L}^{-1}\right)$ \\
\hline EM & $0.48 \pm 0.03$ & $120.34 \pm 10.54$ & $11.62 \pm 1.61$ & $0.51 \pm 0.02$ & $10.01 \pm 0.46$ & $4198 \pm 702$ & $2238 \pm 394$ \\
\hline
\end{tabular}

Given is the $p$-value of a comparison of the means (Mann-Whitney U-test) and the significance level $\left({ }^{*} p<0.05\right)$.

taxa were not closely related to each other and had a largely different ecology. In particular the functionally important traits SRA, length fraction and surface area fraction, which determine the development of root surface area in the most uptake-active 1st- and 2nd-order root segments, showed coherent patterns of change from the first to the fourth root order in all species. Further, the relative variation among the species was smaller than in several important aboveground traits such as leaf size, the size 
Table 6 | Principal components for the relatedness of eight root morphological and chemical traits and root order (order 1-3) with the axes 1-4 of a PCA covering all six species (in brackets: cumulative fit values $R^{2}$ ).

\begin{tabular}{|c|c|c|c|c|}
\hline Variables & Axis 1 & Axis2 & Axis3 & Axis4 \\
\hline Root branching order & $-0.944(0.890)$ & $0.164(0.917)$ & $-0.044(0.919)$ & $0.206(0.962)$ \\
\hline SRA $\left(\mathrm{cm}^{2} \mathrm{~g}^{-1}\right)$ & $0.966(0.933)$ & $0(0.933)$ & $-0.041(0.935)$ & $0.217(0.982)$ \\
\hline $\operatorname{RTD}\left(\mathrm{g} \mathrm{cm}^{-3}\right)$ & $-0.628(0.394)$ & $-0.697(0.880)$ & $0.334(0.992)$ & $0.090(1.000)$ \\
\hline $\mathrm{N}$ concentration $\left(\mathrm{mg} \mathrm{g}^{-1}\right)$ & $0.777(0.604)$ & $0.310(0.700)$ & $0.545(0.997)$ & $-0.015(0.997)$ \\
\hline
\end{tabular}

The eigenvalues of the axes are given in the second row. The closest correlations of the components with the respective axis are given in bold print.

difference between sun and shade leaves, or mean xylem vessel diameter (Köcher et al., 2013; Legner et al., 2013).

On the other hand, several other root traits differed largely between the species. Most variable was root tip frequency (the number of tips per fine root mass) with $\sim 6$ fold difference between the species (smallest in F. excelsior, largest in A. pseudoplatanus) matching results of Ostonen et al. (2007) in three boreal tree species. More relevant for nutrient uptake capacity may be the number of tips per soil volume which still differed about 3.5 fold among the co-occurring species. This variability is also visible in species differences in the cumulative length of 1st-order root segments per soil volume: species means ranged from 2.14 to $7.31 \mathrm{~m} \mathrm{~L}^{-1}$ soil; a substantial part of the first order segment is contributed by the root tip itself. The length of the hyphal net per soil volume is certainly another, probably even more important, morphological factor influencing uptake capacity. Unfortunately, we do not have information on this variable.

A relatively high species variation existed also in the pattern as to how root tissue density and root $\mathrm{N}$ concentration changed from the first to the fourth root order. F. excelsior differed substantially from the other species with lower RTD and higher $\mathrm{N}$ in particular in the second to fourth orders. Thus, apparent convergence in several root traits can go along with markedly diverging patterns in other properties. We reached at similar conclusions when the different soil layers were analyzed separately or the pooled samples of all soil layers were examined. In fact, soil depth exerted only a minor influence on fine root morphology and branching patterns of these six species.

When interpreting the findings from Hainich forest, it is important to recognize that convergence in root traits was detected for the modes of $\mathrm{C}$ and $\mathrm{N}$ allocation within the fine root system, i.e., the trees' strategy to use plant resources for generating nutrient and water capturing surfaces. We speculate that a relatively compact soil (clay content: $20-30 \%$ ) with relatively high bulk density $\left(\sim 1.2 \mathrm{~g} \mathrm{~cm}^{-3}\right.$ in the topsoil $)$ and temporal desiccation in dry summer periods may represent conditions favoring convergence in the root traits examined. All species must face similar physical root growth constraints and a comparable carbon-investment-to-nutrient-return ratio of roots exploring the soil. The much larger species variation in root tip numbers than in branching patterns indicates that this trait must be more under genotypic control than others. Observed species differences in root mass- and surface area-specific nutrient uptake capacity (e.g., Jacob and Leuschner, 2014) might, in part, be a consequence of differences in root tip numbers, but such dependence has not yet been examined. Alternatively, differences in hyphal length and activity, and in root activity per root surface area, may also be influential factors.

The partly deviating fine root properties of F. excelsior (relatively thick, N-rich 1st- and 2nd-order roots with low tissue density and only few root tips), which have already been noted in earlier studies (Meinen et al., 2009a; Jacob et al., 2012), could relate to the ecology of this species. F. excelsior differs in important functional traits from the other investigated species, notably in its relatively high growth rate as an early- to mid-successional species, its ring-porous xylem with large vessels in the stem, and a relatively high $\mathrm{N}$ demand (Ellenberg and Leuschner, 2010; Dobrowolska et al., 2011). F. excelsior further deviated from the other species by a particularly low root biomass: necromass ratio which may point to species differences in fine root mortality in this mixed stand. One might assume that ash as a species with preference of base-rich fertile soils does require lower root tip numbers than other species, but all six species of our study grew on similar soil.

Species differences in fine root properties were also notable between the two closely related Acer species (particularly high SRL and SRA in 1st-order roots of $A$. pseudoplatanus) which is in agreement with the results of Hölscher et al. (2002).

\section{ROOT MORPHOLOGICAL DIFFERENCES BETWEEN EM AND AM TREE SPECIES}

To our surprise, we found significant differences between the three EM and three AM species in only one of the seven root morphological, chemical or branching-related traits. In both groups, considerable among-species variation existed for the variables tip number per root mass and tip number per soil volume. Despite the contrasting modes of interaction between root and fungus in the two mycorrhiza types, the EM species ( $C$. betulus, T. cordata, F. sylvatica) on average did not form more root tips per root mass or soil volume than the AM species (Acer spp. and F. excelsior), where the fungus infects larger sections of the root than in EM trees. In our EM species, we observed insertion of hyphae mainly in the tip with the Hartig net but also in the directly adjacent parts of the 1st and 2 nd root orders. While nearly all tips were colonized by fungi in the three EM species ( $~ 96 \%$ according to the study of Lang et al., 2011 in Hainich forest), only about 19\% of 


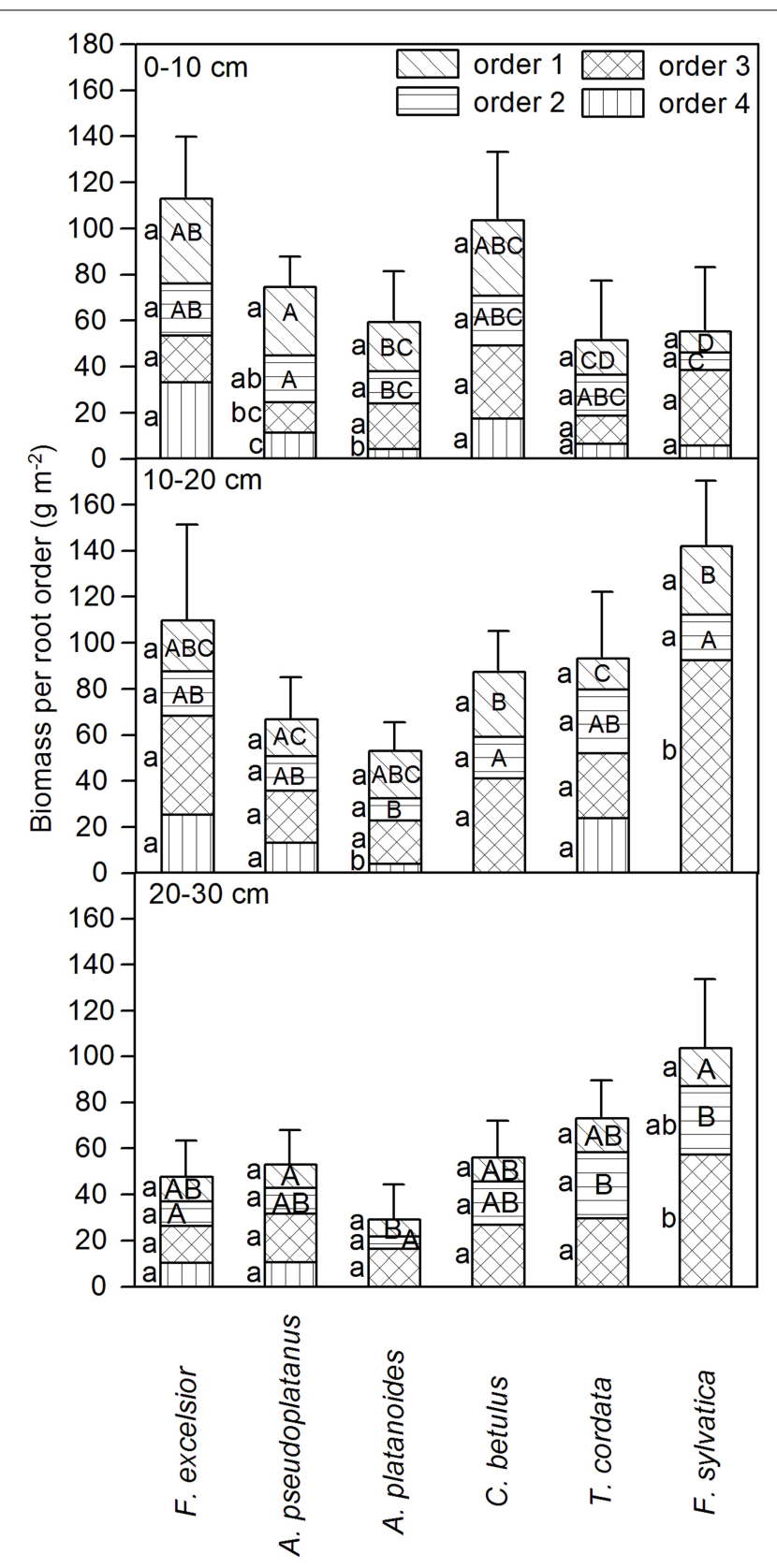

FIGURE 2 | Fine root biomass assigned to the root orders 1-4 (uppermost to lowermost sections of bars) in three soil depths (0-10, 10-20, and 20-30 cm, in $\mathrm{g} \mathrm{m}^{-2} 10 \mathrm{~cm}$ depth $^{-1}$ ) for the six tree species (means \pm SE). Different small letters mark significant differences between root orders for a species, different capital letters significant differences in a given order between the species (only 1st and 2nd order); Mann-Whitney $U$-test; $p<0.05$.

the roots of Fraxinus and Acer were found to be infected by AM fungi (Lang et al., 2011). Largely different between the two groups was also the diversity of colonizing fungi in this mixed forest (75, 68, and 43 EM fungal species in Fagus, Tilia, and Carpinus, and 7 different taxa of glomeromycota in the AM species according to ITS sequencing, Lang et al., 2011). It appears that, at least in the studied six species, the type of mycorrhiza is not an important determinant of fine root branching patterns and morphology despite the contrasting patterns of symbiotic interaction. This is somewhat surprising because it is well recognized that colonizing EM fungi have major effects on root morphology and architecture by inducing the formation of short lateral roots and root tips that become swollen with a coralloid or "Christmas-tree" like structure (Smith and Read, 1997). Infection by AM-forming fungi appears to have more subtle effects on root morphology and architecture with changes observed in branching patterns and in the length of 2nd- and 3rd-order root segments (Hetrick, 1991; Hooker et al., 1992). Thus, infections either by glomeromycota (AM) or basidio- or ascomycetes (EM) both tend to alter fine root morphology, but the morphogenetic effect has not yet been compared for AM and EM trees in a shared soil volume. We also found no clear hints for an important influence of mycorrhiza type on root functioning, because aboveground productivity was not systematically different between the AM and EM trees in Hainich forest, and neither foliar nor fine root $\mathrm{N}$ concentration showed clear differences between EM and AM species in this forest (Jacob et al., 2010).

At least in the fertile soils of Hainich forest, other factors such as species differences in standing fine root biomass, in fine root turnover, and in local nutrient availability as resulting from tree species effects on soil chemistry (Rothe and Binkley, 2001; Guckland et al., 2009) may be more relevant for root functioning than the type of mycorrhiza. The sheer number of root tips also does not seem to be a relevant factor for tree nutrition in this forest, because A. pseudoplatanus with highest fine root tip numbers per root mass and soil volume among the six species did not possess higher fine root and foliar $\mathrm{N}$ concentrations and was not more productive than the other species.

\section{THE IMPORTANCE OF 1st- AND 2nd-ORDER ROOT SEGMENTS}

The root order-related analysis of fine root biomass showed that only a half to a third of the conventionally sampled fine root biomass $(<2 \mathrm{~mm}$ in diameter) referred to 1 st- and 2 nd-order segments in our study and that this fraction was more variable among the six species than bulk fine root biomass. We also found that the relative proportion of these two root fractions is highest in the topsoil $(0-10 \mathrm{~cm})$, while $3 \mathrm{rd}$ - and 4 th-order segments are more important lower down in the profile where the supply of nitrogen (and other nutrients) is lower and small-diameter roots may primarily have transport functions. Lower root physiological activity deeper in the soil is also suggested by an increasing root $\mathrm{C} / \mathrm{N}$ ratio with increasing soil depth in our soil profiles (data not shown); this matches results of Gaul et al. (2009) from spruce forest soils.

Our data on order-specific fine root biomass per ground area of mature trees can be compared with only very few other studies (e.g., Guo et al., 2004; Wang et al., 2006; Sun et al., 2011). These studies are, however, only partly equivalent to our study because they refer to immature stands, sampled only the topsoil $(0-10$ or $20 \mathrm{~cm})$ and compared only two species with inclusion of conifers. Nevertheless, it appears that different tree species may differ considerably with respect to the proportion of 1st- and 2ndorder roots in fine root biomass. More comparative studies in 
other forest types are needed for quantifying this root fraction and examining the link to tree resource uptake and productivity.

\section{CONCLUSIONS}

Comparative fine root system analysis in the Hainich mixed forest, either by examining bulked fine root samples $(<2 \mathrm{~mm}$ in diameter) or through detailed analysis of root orders, revealed that the more precise, but highly labor-intensive, order-based analysis detected several species differences that would have been overlooked in the more rapid analysis of bulked samples. However, species differences in the important traits SRA, root $\mathrm{N}$ concentration and MD were also reflected in the bulk analysis. Thus, for many purposes, it may be sufficient to analyze bulked root material (e.g., in the diameter class $<1$ or $<2 \mathrm{~mm}$ ) for characterizing morphological differences between, and similarities among, temperate tree species. Nevertheless, studies in additional tree species have to show, whether the detected convergent patterns in SRA and in the length and surface area fractions along fine root strands are indeed more or less similar among different temperate tree species.

The comparison of AM and EM tree species revealed no systematic fine root morphological differences between the two mycorrhiza types except for SRA. We suggest searching more systematically for different structural and functional consequences of the formation of either AM or EM symbioses in temperate tree species. Our approach of investigating arbuscular and ectomycorrhizal species of the same plant life form in a mixed stand may shed new light on the old discussion about principal functional differences between these two types of plant-fungus interaction.

\section{ACKNOWLEDGMENTS}

The authors want to acknowledge all persons who contributed to data collection, installations in the field and laboratory assistance. Special thanks go to Andreas Jacob and Mechthild Stange for support during lab work and with the methodology. This research is part of the Research Training Group GRK 1086 funded by the German Research Foundation (DFG) (http://www.unigoettingen.de/de/82664.html).

\section{SUPPLEMENTARY MATERIAL}

The Supplementary Material for this article can be found online at: http://www.frontiersin.org/journal/10.3389/fpls.2015. 00064/abstract

\section{REFERENCES}

Dobrowolska, D., Hein, S., Oosterbaan, A., Wagner, S., Clark, J., and Skovsgaard, J. P. (2011). A review of european ash (Fraxinus excelsior L.): implications for silviculture. Forestry 84, 133-148. doi: 10.1093/forestry/cpr001

Ellenberg, H., and Leuschner, C. (2010). Vegetation Mitteleuropas mit den Alpen 6. Stuttgart: Ulmer Verlag.

Fitter, A. (1996). "Characteristics and functions of root systems," in Plant Roots: The Hidden Half 3, eds U. Kafkafi, Y. Waisel, and A. Eshel (New York, NY: Marcel Dekker Inc.), 15-32.

Gaul, D., Hertel, D., and Leuschner, C. (2009). Estimating fine root longevity in a temperate norway spruce forest using three independent methods. Funct. Plant Biol. 36, 11-19. doi: 10.1071/FP08195

George, E., Marschner, H., and Jakobsen, I. (1995). Role of arbuscular mycorrhizal fungi in uptake of phosphorus and nitrogen from soil. Crit. Rev. Biotech. 15, 257-270. doi: 10.3109/07388559509147412
Guckland, A., Jacob, M., Flessa, H., Thomas, F. M., and Leuschner, C. (2009). Acidity, nutrient stocks, and organic-matter content in soils of a temperate deciduous forest with different abundance of European beech (Fagus sylvatica L.). J. Plant Nutr. Soil Sci. 172, 500-511. doi: 10.1002/jpln.200800072

Guo, D. L., Mitchell, R. J., and Hendricks, J. J. (2004). Fine root branch orders respond differentially to carbon source-sink manipulations in a longleaf pine forest. Oecologia 140, 450-457. doi: 10.1007/s00442-004-1596-1

Guo, D., Xia, M., Wei, X., Chang, W., Liu, Y., and Wang, Z. (2008). Anatomical traits associated with absorption and mycorrhizal colonization are linked to root branch order in twenty-three chinese temperate tree species. New Phytol. 180, 673-683. doi: 10.1111/j.1469-8137.2008.02573.x

Hertel, D., and Leuschner, C. (2002). A comparison of four different fine root production estimates with ecosystem carbon balance data in a Fagus - Quercus mixed forest. Plant Soil 239, 237-251. doi: 10.1023/A:1015030320845

Hetrick, B. A. D. (1991). Mycorrhizas and root architecture. Experientia 47, 355-362. doi: 10.1007/BF01972077

Hölscher, D., Hertel, D., Leuschner, C., and Hottkowitz, M. (2002). Tree species diversity and soil patchiness in a temperate broad-leaved forest with limited rooting space. Flora 197, 118-125. doi: 10.1078/0367-2530-00021

Hooker, J. E., Munro, M., and Atkinson, D. (1992). Vesicular-arbuscular mycorrhizal fungi induced alteration in poplar root system morphology. Plant Soil 145, 207-214. doi: 10.1007/BF00010349

Jacob, A., Hertel, D., and Leuschner, C. (2012). On the significance of belowground overyielding in temperate mixed forests: separating species identity and species diversity effects. Oikos 122, 463-473. doi: 10.1111/j.1600-0706.2012.20476.x

Jacob, A., and Leuschner, C. (2014). Complementarity in the use of nitrogen forms in a temperate broad-leaved mixed Forest. Plant Ecol. Divers. 1-16. doi: $10.1080 / 17550874.2014 .898166$

Jacob, M., Leuschner, C., and Thomas, F. M. (2010). Productivity of temperate broad-leaved forest stands differing in tree species diversity. Ann. For. Sci. 67, 503. doi: 10.1051/forest/2010005

Köcher, P., Gebauer, T., Horna, V., and Leuschner, C. (2009). Leaf water status and stem xylem flux in relation to soil drought in five temperate broad-leaved Tree species with contrasting water use strategies. Ann. For. Sci. 66, 101. doi: $10.1051 /$ forest/2008076

Köcher, P., Horna, V., and Leuschner, C. (2013). Stem water storage in five coexisting temperate broad-leaved tree species: significance, temporal dynamics and dependence on tree functional traits. Tree Physiol. 33, 817-832. doi: 10.1093/treephys/tpt055

Korn, S. (2004). Experimentelle Untersuchung der Wasseraufnahme und der hydraulischen Eigenschaften des Wurzelsystems. Ph.D. thesis, University of Göttingen, Germany.

Lang, C., Seven, J., and Polle, A. (2011). Host preferences and differential contributions of deciduous tree species shape mycorrhizal species richness in a mixed central european forest. Mycorrhiza 21, 297-308. doi: 10.1007/s00572010-0338-y

Legner, N., Fleck, S., and Leuschner, C. (2013). Within-canopy variation in photosynthetic capacity, SLA and foliar $\mathrm{N}$ in temperate broad-leaved trees with contrasting shade tolerance. Trees 28, 263-280. doi: 10.1007/s00468-0130947-0

Leuschner, C., Hertel, D., Schmid, I., Koch, O., Muhs, A., and Hölscher, D. (2004). Stand fine root biomass and fine root morphology in old-growth beech forests as a function of precipitation and soil fertility. Plant Soil 258, 43-56. doi: 10.1023/B:PLSO.0000016508.20173.80

Meinen, C., Hertel, D., and Leuschner, C. (2009b). Root growth and recovery in temperate broad-leaved forest stands differing in tree species diversity. Ecosystems 12, 1103-1116. doi: 10.1007/s10021-009-9271-3

Meinen, C., Hertel, D., and Leuschner, C. (2009a). Biomass and morphology of fine roots in temperate broad-leaved forests differing in tree species diversity: is there evidence of below-ground overyielding? Oecologia 161, 99-111. doi: 10.1007/s00442-009-1352-7

Meinen, C., Leuschner, C., Ryan, N. T., and Hertel, D. (2009c). No evidence of spatial root system segregation and elevated fine root biomass in multi-species temperate broad-leaved forests. Trees 23, 941-950. doi: 10.1007/s00468-0090336-x

Ostonen, I., Lohmus, K., Helmisaari, H.-S., Truu, J., and Meel, S. (2007). Fine root morphological adaptations in Scots pine, Norway spruce and silver birch along a latitudinal gradient in boreal forests. Tree Physiol. 27, 1627-1634. doi: 10.1093/treephys/27.11.1627 
Ostonen, I., Rosenvald, K., Helmisaari, H.-S., Godbold, D., Parts, K., Uri, V., et al. (2013). Morphological plasticity of ectomycorrhizal short roots in Betula sp and Picea abies forests across climate and forest succession gradients: its role in changing environments. Front. Plant Sci. 4:335. doi: 10.3389/fpls.2013.00335

Pregitzer, K. S. (2002). Fine roots of trees - a new perspective. New Phytol. 154, 267-270. doi: 10.1046/j.1469-8137.2002.00413_1.x

Pregitzer, K. S., Deforest, J. L., Burton, A. J., Allen, M. F., Ruess, W., and Hendrick, R. L. (2002). Fine root architecture of nine north american trees. Ecol. Monogr. 72, 293-309. doi: 10.1890/0012-9615(2002)072[0293:FRAONN]2.0.CO;2

Pregitzer, K. S., Kubiske, M. E., Yu, C. K., and Hendrick, R. L. (1997). Relationships among root branch order, carbon, and nitrogen in four temperate species. Oecologia 111, 302-308. doi: 10.1007/s004420050239

Pregitzer, K. S., Laskowski, M. J., Burton, A. J., Lessard, V. C., and Zak, D. R. (1998). Variation in sugar maple root respiration with root diameter and soil depth. Tree Physiol. 18, 665-670. doi: 10.1093/treephys/18.10.665

Read, D. J., and Perez-Moreno, J. (2003). Mycorrhizas and nutrient cycling in ecosystems - a journey towards relevance? New Phytol. 157, 475-492. doi: 10.1046/j.1469-8137.2003.00704.x

Rewald, B., and Leuschner, C. (2009). Belowground competition in a broad-leaved temperate mixed forest: pattern analysis and experiments in a four-species stand. Eur. J. For. Res. 128, 387-398. doi: 10.1007/s10342-009-0276-4

Rothe, A., and Binkley, D. (2001). Nutritional interactions in mixed species forests: a synthesis. Can. J. For. Res. 31, 1855-1870. doi: 10.1139/x01-120

Schmidt, I., Leuschner, C., Mölder, A., and Schmidt, W. (2009). Structure and composition of the seed bank in monospecific and tree speciesrich Temperate broad-leaved forests. For. Ecol. Manag. 257, 695-702. doi: 10.1016/j.foreco.2008.09.052

Seidel, D., Fleck, S., and Leuschner, L. (2012). Analyzing forest canopies with ground-based laser scanning: a comparison with hemispherical photography. Agric. For. Meteorol. 154, 1-8. doi: 10.1016/j.agrformet.2011.10.006

Smith, S. E., and Read, D. J. (1997). Mycorrhizal symbiosis. Acad. Press 2, 33-80. doi: 10.1016/B978-012652840-4/50007-3

Smith, S. E., Smith, F. A., and Jacobsen, I. (2003). Mycorrhizal fungi can dominate phosphate supply to plants irrespective of growth responses. Plant Physiol. 133, 16-20. doi: 10.1104/pp.103.024380
Sun, Y., Gu, J., Zhuang, H., Guo, D., and Wang, Z. (2011). Lower order roots more palatable to herbivores: a case study with two temperate tree species. Plant Soil 347, 351-361. doi: 10.1007/s11104-011-0854-3

Van Praag, H. J., Sougnez-Remy, S., Weissen, F., and Carletti, G. (1988). Root turnover in a beech and a spruce stand of the belgian ardennes. Plant Soil 105, 87-103. doi: 10.1007/BF02371146

Vockenhuber, E. A., Scherber, C., Langenbruch, C., Meißner, M., Seidel, D., and Tscharntke, T. (2011). Tree diversity and environmental context predict herb species richness and cover in Germany's largest connected deciduous forest. Perspect. Plant Ecol. Evol. Syst. 13, 111-119. doi: 10.1016/j.ppees.2011.02.004

Wang, Z., Guo, D., Wang, X., Gu, J., and Mei, L. (2006). Fine root architecture, morphology, and biomass of different branch orders of two chinese temperate tree species. Plant Soil 288, 155-171. doi: 10.1007/s11104-006-9101-8

Withington, J. M., Reich, P. B., Oleksyn, J., and Eissenstat, D. M. (2006). Comparisons of structure and life span in roots and leaves among temperate trees. Ecol. Monogr. 76, 381-397. doi: 10.1890/00129615(2006)076[0381:COSALS $] 2.0$. CO;2

Conflict of Interest Statement: The authors declare that the research was conducted in the absence of any commercial or financial relationships that could be construed as a potential conflict of interest.

Received: 08 October 2014; accepted: 25 January 2015; published online: 11 February 2015.

Citation: Kubisch P, Hertel D and Leuschner C (2015) Do ectomycorrhizal and arbuscular mycorrhizal temperate tree species systematically differ in root order-related fine root morphology and biomass? Front. Plant Sci. 6:64. doi: 10.3389/fpls.2015.00064

This article was submitted to Functional Plant Ecology, a section of the journal Frontiers in Plant Science.

Copyright (C) 2015 Kubisch, Hertel and Leuschner. This is an open-access article distributed under the terms of the Creative Commons Attribution License (CC BY). The use, distribution or reproduction in other forums is permitted, provided the original author(s) or licensor are credited and that the original publication in this journal is cited, in accordance with accepted academic practice. No use, distribution or reproduction is permitted which does not comply with these terms. 